Article

\title{
Social Responsibility Initiatives for Public-Private Partnership Projects: A Comparative Study between China and Ghana
}

\author{
Robert Osei-Kyei ${ }^{1}$, Albert P. C. Chan ${ }^{2}$, Yao Yu ${ }^{2,3}$, Chuan Chen ${ }^{3, *}$, Yongjian $\mathrm{Ke}^{4}$ and \\ Bashir Tijani ${ }^{1}$ \\ 1 School of Computing, Engineering and Mathematics, Western Sydney University, Penrith NSW 2751, Australia; \\ R.Osei-Kyei@westernsydney.edu.au (R.O.-K.); 17872544@student.westernsydney.edu.au (B.T.) \\ 2 Department of Building and Real Estate, The Hong Kong Polytechnic University, Hong Hum, \\ Kowloon, Hong Kong; albert.chan@polyu.edu.hk \\ 3 Business School, Sichuan University, Chengdu 610065, China; yuyaoscu@126.com \\ 4 School of Built Environment, University of Technology Sydney, Sydney 2007, Australia; \\ yongjian.ke@uts.edu.au \\ * Correspondence: chenchuanscu@126.com
}

Received: 27 January 2019; Accepted: 26 February 2019; Published: 4 March 2019

\begin{abstract}
Sustainability is a global issue and its enhancement through modern forms of procurements, such as public-private partnership (PPP), has become topical considering the huge impact of PPP activities on society, the economy, and the environment. However, one way of promoting sustainability thorough PPPs is the adoption of social responsibility (SR) initiatives/factors. This paper aims to empirically investigate the SR factors in PPPs through a comparative study between China and Ghana. An empirical questionnaire survey was conducted in both China and Ghana. Further, the mean score ranking, Kendall's coefficient of concordance, and Mann-Whitney $\mathrm{U}$ test were used for data analysis. Results show that SR factors related to the economic efficiency of PPP projects and climate change adaptation are critical in China, whereas in Ghana, SR factors directly related to job creation and environmental protection are critical. The outputs of this study inform investors of the critical SR initiatives to consider when engaging in PPPs in Asia and Africa. In addition, they provide a solid knowledge base for the continuous international debate on how sustainability could be enhanced through PPP policy.
\end{abstract}

Keywords: public-private partnership; social responsibility; sustainability; sustainable development; China; Ghana

\section{Introduction}

The concept of public-private partnership (PPP) has continuously evolved over the past couple of decades and it is now argued to have considerable advantages over the traditional bid build method [1,2]. In fact, PPP is seen by many governments as a major tool to bridge their huge infrastructure gap and minimize pressure on the public purse [3]. A report by the World Bank [4] indicated that in 2016, around 242 PPP projects accounting for US $\$ 71.5$ billion were initiated in emerging markets and developing economies. Of these investments, the Latin America and Caribbean region, driven by Brazil, had the highest share of the investments. Other regions with an increase in PPP investments included East Asia and Pacific, and South Asia. Indeed, these outcomes clearly show the growing interest by many governments, particularly those in developing countries, in the PPP concept.

Importantly, one critical issue that is emerging with the rapid development of PPPs is how sustainability could be enhanced through the PPP concept [5,6]. Generally, sustainability is a very 
topical issue in construction; however, its enhancement through modern forms of procurement, such as PPPs, has become a major concern for both practitioners and academics [5]. This is because PPP involves a complex myriad of activities and negotiations, which affect organizations, society, the economy, and the environment [5,6]. Importantly, one way of promoting sustainability in PPPs is the adoption of social responsibility (SR) initiatives/measures [7]. SR refers to the obligations of an organization/institution towards the benefits of society $[7,8]$. Through SR initiatives/measures, PPP projects are able to offer enough social benefits as well as enhancing value for money [9]. Emphatically, many past PPP projects that failed to employ more SR measures, including job opportunities, affordability, low carbon emission, and environmental safety, have resulted in fierce political opposition and public agitation $[10,11]$. Therefore, it is necessary for practitioners (both public and private sector organizations) to have an in-depth knowledge and understanding on the available SR initiatives that could be employed in PPPs to achieve economic, social, and environmental balance.

Undoubtedly, a considerable amount of research has been vested in PPP implementation over the last couple of decades [12,13]. Essentially, most of the past research studies focused on issues, such as risk assessment and allocation [14-17]; critical success factors [18-23]; reasons/drivers [24-26]; and obstacles $[1,9,27]$. Other past publications also focused on specific sectors, particularly the health sector [28]. However, very few, if any, have attempted to explore sustainability, particularly social responsibility, in PPP implementation - a very critical and emerging issue. Although Yu et al. [7] investigated into SR in PPPs, they only reviewed and generated a checklist of SR factors. Importantly, they did not empirically test the SR framework with practitioners to identify the most critical SR factors that practitioners should consider when initiating PPP projects. Also, Brammer and Walker [29] focused on the sustainability of public procurement, but failed to examine critically the SR initiatives and sustainability issues in PPPs. Therefore, given that sustainable development is important to many governments and the fact that adopting SR initiatives in PPPs is key in its promotion, there is a need for more empirical research to be conducted to explore the essential SR factors in PPPs.

Against this background, this paper aims to explore and evaluate the SR initiatives for PPP projects through a comparative study between China and Ghana. A comparative study is adopted because it provides implications that are not only beneficial to PPP practitioners in a particular jurisdiction, as seen in many past PPP studies, but rather it offers suggestions that are useful to international private investors and governments who are yet to adopt the PPP concept for sustainable development. Notwithstanding, the PPP concept has become global, therefore, implications that will improve the international best practice framework of PPPs are crucial in recent times.

The outputs of this study will inform international private investors interested in PPPs in Asia and Africa of the critical SR initiatives/measures that should be employed to enhance wider social benefits and increase value for money. Also, governments who are yet to adopt the PPP concept will be informed of the sustainability initiatives that need to be considered when engaging in competitive negotiations with private investors. Lastly, the findings of this paper serve as foundation for further empirical research studies on the development of a sustainability index or model for PPP project arrangements.

\section{Overview of Research Studies on Public-Private Partnership}

The PPP concept has gained popularity over the last couple of decades in both developing and developed countries. It was first introduced in the construction industry as cooperative institutional arrangements between the public and private sectors [30]. Today, the PPP concept is seen to offer many benefits, such as reduced public sector administrative costs in procuring public infrastructure, value for money, efficient risk allocation, access to the public sector market, and technology transfer, compared to the traditional build-bid projects $[18,24,26]$. The concept has also been well established in many infrastructural sectors, such as water treatment, transportation, defense, educational facilities, public housing, public health, and amusement parks $[13,28,31]$. Though PPP has become very useful to national development, it is certainly not a panacea for infrastructure development. In fact, more 
efforts are required by policy makers and governments, particularly those in developing countries, to find alternative solutions to the rapid increase in the demand for infrastructure development [32].

Since PPP first emerged, some countries have progressed rapidly with its implementation, whereas many are yet to undertake full-scale implementation of the policy. The major reasons for this situation include the high cost of transaction, poor legal environment, lack of accountability, political interference, weak public institutional structures, high use of unsolicited proposals, and poor macroeconomic conditions $[11,30]$. Because of the many reported problems, the last decade has seen a large strand of research studies investigating how to deliver PPPs successfully (i.e., critical success factors for PPPs) [33]. Other studies have also focused on how risks could be shared and managed efficiently among project parties [17]. The majority of studies on risk management in PPPs concluded that risks should be allocated to the party with a better mitigation plan and capability. Further, the public sector should not attempt to impose too many risks on the private sector [14]. Value for money in PPPs has also been extensively studied by many researchers [24]. Some value for money measures proposed by past studies include the provision of output-based specifications instead of detailed input specification, competitive tendering, and technological innovation [24].

Despite the existence of a large strand of literature on PPPs, sustainability in PPPs has received little attention in the normative literature. This is not surprising because sustainability has only become topical in infrastructure development recently (after careful consideration by policy makers and governments for the need to preserve the environment and ecosystem). Thus, previous studies on PPPs may not have considered it as being critical. However, in modern times, it has become imperative for researchers to focus on how sustainability and social responsibility could be enhanced through the PPP concept due to the complexities and detrimental effects that PPPs can have on the society and ecosystem. This study therefore seeks to contribute to the ongoing debate and discussion on how sustainability and social responsibility initiatives could be promoted through PPPs.

\section{Review of Social Responsibility (SR) Factors for Sustainable Development in PPPs}

Social responsibility integrates social, environmental, and ethical human rights and user concerns into an operation or process [34]. Through SR initiatives, organizations are able to incorporate in their strategy and decisions the social and environmental effects of their activities [8]. SR is an important issue in PPPs because it has become the agenda of many governments to promote sustainable development-a development that meets the needs of the present without compromising the ability of future generations to meet their own needs [5]. Though many governments are keen to bridge their huge infrastructure gaps through PPPs, they are also conscious of the fact that PPPs involve a complex myriad of activities; therefore, they have a huge impact on society, the economy, and the environment [35]. Similarly, while private sector organizations aim to make more profits through PPPs [24,25,36], they are aware of how society is affected by PPP activities and agreements [7].

The majority of SR initiatives often adopted in PPPs are focused in areas, such as environmental health and safety, poverty reduction, sanitation, education, and transparency [9,35]. Ensuring transparency and anti-corruption is critical in gaining the general public's positive perception of PPPs [37]. Society tends to react negatively by engaging in demonstrations when PPP contract details and tendering process are not made public. It becomes even more irritating to society when project parties attempt to justify their lack of transparency on the basis of confidentiality. As suggested by the Danish International Development Agency (DANIDA) [38], the private sector organization should work against all forms of corruption, such as extortion and bribery, when engaging in PPP deals. Likewise, public officials, particularly political leaders, should desist from influencing the selection process.

Job creation is an essential SR initiative in PPPs [39,40]. This SR factor is even more critical in communities and regions with high unemployment youth rates [7]. Considering that PPP is a long-term contract, which involves a series of activities, it is generally expected that the numerous activities, including construction, operation, and maintenance, will provide job opportunities to local residents [41]. The job opportunities will enable unemployed local residents to get some source of 
livelihood and therefore improve their standard of living. In fact, in some situations, the activities in the PPP project lifecycle may not necessarily need to provide jobs, but upon completion of the project, opportunities should be available for local residents to engage in commercial activities and enterprises [33]. The quality of service is also reported to be important in ensuring SR in PPPs [42,43]. It implies a delivery of services that is in line with output specifications and standards. The provision of services that meet the expectations of users helps eradicate the negative perceptions of the general public of PPP deals. On the other hand, when the quality of service is poor and below expectations, users tend to raise questions on whether the value for money was thoroughly assessed.

\section{Research Methodology}

\subsection{Pilot Study}

The checklist of SR factors developed by Yu et al. [7] was adopted for this study. However, to ensure the applicability and suitability of the checklist within the Chinese and Ghanaian context, six PPP experts, three from each country, were invited to review the checklist. The experts were selected based on their in-depth experience and knowledge on PPP practice (i.e., $>10$ years) within the Chinese and Ghanaian context. The experts recommended that some SR factors should be rephrased, including "protecting cultural heritage", "noise prevention", and "improving local policy". The finalized set of SR factors is shown in Table 1.

\subsection{Collection of Data}

A questionnaire survey was conducted in both China and Ghana with experts to evaluate and compare the significance of 30 SR factors for PPPs. Apparently, surveys are one of the most widely used research methods in PPP research because of the sensitive nature of issues related to it [37]. Notwithstanding, the questionnaire survey method is usually appropriate for comparative studies because it allows the researcher to measure parameters among two jurisdictions on the same basis using a common research instrument. In this regard, a survey was considered suitable to evaluate the SR factors among China and Ghana. The questionnaire requested the respondents to rate the importance of each SR factor on a five-point Likert scale as applied in their respective jurisdiction. Targeted respondents were selected based on two criteria: (1) Having in-depth knowledge of PPPs, including following the development of PPPs in China or Ghana closely; and (2) having adequate direct hands-on and/or research experience in terms of publications in China or Ghana [26].

Considering these pre-defined criteria, 170 and 150 potential respondents in China and Ghana, respectively, were identified and invited to participate in the study. Essentially, many of the respondents from China were from cities that have vibrant PPP markets. These include Beijing, Qingdao, Chengdu, and Yibin. Whereas in Ghana, the majority of the identified respondents came from public institutions that are actively involved in PPP deals (e.g., Ghana Highways Authority, PPP Advisory Unit, Urban Roads Department, Ministry of Trade and Industry) [44]. Questionnaires were distributed to respondents by face-to-face meetings and/or email. Specifically, questionnaires distributed in cities in Sichuan Province, i.e., Chengdu and Yibin, were distributed by face-to-face, whereas those distributed in Beijing and Qingdao were by email. For Ghana, questionnaires were sent to potential respondents solely by email. Overall, 84 responses were received; 34 from China and 52 from Ghana [44]. These represent response rates of $18.82 \%$ and $34.67 \%$ for China and Ghana, respectively. Essentially, the response rates from both countries are low, however, the sample sizes are considered suitable for further analysis when compared with similar comparative studies conducted in PPPs (e.g., Chan et al. [3] obtained 53 and 34 replies from China and Hong Kong, respectively; Cheung et al. obtained 34 and 11 responses from Hong Kong and Australia, respectively; and Liu et al. obtained 25 and 32 replies from Australia and China, respectively) [44]. 
Table 1. Finalized list of social responsibility factors in Public-Private Partnership (PPP).

\begin{tabular}{|c|c|}
\hline Social Responsibility Factors in PPP & Literature \\
\hline Improve resource performance and efficiency & {$[41,45,46]$} \\
\hline Profitability & {$[6,46]$} \\
\hline Innovation & {$[46,47]$} \\
\hline Improve project quality & {$[39,41,48]$} \\
\hline Cost reduction & {$[6,39,48]$} \\
\hline Efficient maintenance & {$[6,49]$} \\
\hline Proper contract & {$[50,51]$} \\
\hline Ensure project is completed on time and budget & {$[6,52]$} \\
\hline Support local business & [53] \\
\hline Improve local policy & [48] \\
\hline Ensure accountability, legitimacy and transparency & {$[53,54]$} \\
\hline Keep close partnership between stakeholders & {$[45,53]$} \\
\hline Improve service standard & {$[6,55]$} \\
\hline Provide jobs & {$[39,49]$} \\
\hline Ensure worker health and safety & {$[46,49]$} \\
\hline Protect human rights & {$[46,49]$} \\
\hline Working altruistically for the public good & {$[53]$} \\
\hline Protect cultural heritage & [46] \\
\hline Appropriate resettling, rehabilitation, and compensation & [46] \\
\hline Establish a waste emission management system & {$[48,49,55]$} \\
\hline Water protection & {$[5,46,48]$} \\
\hline Improve climate resilience and air quality & {$[42,45,46]$} \\
\hline Improve environmental policy & {$[45,49,55]$} \\
\hline Use sustainable design and materials & {$[42,55,56]$} \\
\hline Reduce carbon emission & {$[41,45]$} \\
\hline Soil protection & {$[46,49]$} \\
\hline Noise prevention & {$[46]$} \\
\hline Biodiversity protection & [46] \\
\hline Landfill protection & [40] \\
\hline Forest protection & [57] \\
\hline
\end{tabular}

Adapted from [7].

These notwithstanding, the majority of respondents from China (i.e., 78\%) and Ghana (i.e., 79\%) are industry practitioners (public and private sectors), which implies that most of the respondents are involved with the intricacies and actualities of PPP practices in both countries. Moreover, a large number of the respondents from both countries (i.e., $84.4 \%$ from China and $80.8 \%$ from Ghana) have more than 5 years of industrial and/or research experience in PPPs. Therefore, this signifies the authenticity of the survey responses for further analysis. A detailed background of the respondents from both countries is shown in Table 2 [44].

Table 2. Background of respondents from China and Ghana.

\begin{tabular}{ccccc}
\hline \multirow{2}{*}{ Characteristics } & \multicolumn{2}{c}{ China } & \multicolumn{2}{c}{ Ghana } \\
\cline { 2 - 5 } & Number of Replies & Percentage & Number of Replies & Percentage \\
\hline \multirow{2}{*}{ Academic } & 7 & Sector of PPP & \\
Public & 13 & 21.9 & 11 & 21.2 \\
Private & 12 & 40.6 & 24 & 46.2 \\
Total & 32 & 37.5 & 17 & 32.7 \\
& Years of PPP experience in the industry and/or research & 100.0 \\
$\leq 5$ & 5 & 15.6 & 10 & 19.2 \\
$6-15$ & 22 & 68.8 & 30 & 57.7 \\
$\geq 16$ & 5 & 15.6 & 12 & 23.1 \\
Total & 32 & 100.0 & 52 & 100.0 \\
\hline
\end{tabular}




\subsection{Tools for Data Analysis}

The Statistical Package for Social Sciences (SPSS) was used to conduct a statistical analysis, including Kendall's coefficient of concordance, mean analysis, and Mann Whitney $U$ test. First, considering that respondents from different PPP sectors (i.e., academic, public, and private) participated in this study, the Kendall's concordance test was conducted to determine the level of consistency and agreement among the responses from each respondent group (i.e., China and Ghana) [58]. The test was conducted at a significance level of 0.05 , thus a significance test value below 0.05 indicates that there is significant consistency and association on the rankings furnished by the respondents [59]. Second, a mean analysis was conducted to evaluate the importance of each SR factor in each jurisdiction. However, to determine the critical SR factors that need careful attention from practitioners in each jurisdiction, the range normalization technique was conducted. Lastly, the Mann- Whitney U test was conducted to ascertain the significant differences in the rankings of the SR factors between China and Ghana. The test was conducted at a significance level of 0.05 , thus a significance test value below 0.05 signifies that respondents from both countries have varying views on the importance of that SR factor.

\section{Results and Discussion}

\subsection{Consistency and Agreement Test}

Kendall's coefficient concordance test was conducted to ascertain the level of consistency and association among responses in each independent group (i.e., China or Ghana). The test was conducted with a null hypothesis that there is no degree of consistency among the rankings of the SR factors. In this regard, a significance test value below 0.05 rejects the null hypothesis. As shown in Table 3, the Kendall's concordance (W) for China and Ghana are 0.314 and 0.236 , respectively; further, each independent group has a significance test value of 0.00 . Therefore, the null hypothesis is rejected, signifying that there is a significant degree of consistency and homogeneity on the rankings of the 30 SR factors within each respondent group. This therefore reaffirms the reliability and authenticity of the survey responses furnished by the experts in each country.

Table 3. Kendall's coefficient of the concordance test results.

\begin{tabular}{cccc}
\hline Characteristics & China & Ghana & China and Ghana \\
\hline Number of survey respondents (N) & 32 & 52 & 84 \\
Kendall's Coefficient of Concordance (W) & 0.314 & 0.236 & 0.163 \\
Chi-Square & 291.701 & 356.147 & 397.178 \\
Degree of freedom (df) & 29 & 29 & 29 \\
Critical value of chi-square & 42.557 & 42.557 & 42.557 \\
Asymp. Sig. & 0.000 & 0.000 & 0.000 \\
\hline
\end{tabular}

\subsection{Mean Analysis and Significant Difference(s) on the Rankings of SR Factors in China and Ghana}

Table 4 presents the mean score rankings of the 30 SR factors in China and Ghana. As indicated in the table, the mean scores for China range from 2.50 to 4.66, whereas the scores for Ghana range between 2.94 and 4.46. The variation in responses are 2.16 and 1.52 for China and Ghana, respectively. Clearly, this shows that the Ghanaian respondents generally ranked the set of factors more similarly than their Chinese counterparts. In addition, the Ghanaian respondents rated the set of SR factors as being higher than their Chinese counterparts. Further detailed analysis using the range normalization method indicates that 11 SR factors are critical in China, whereas in Ghana, 18 SR factors are critical. This implies that the set of SR factors is generally more important in Ghana compared to China. This outcome is unsurprising because China has a matured PPP market, therefore, it successfully employed more SR measures over the last decade. Whereas in Ghana, the PPP concept was revitalized in 2011 and since then, few projects have been implemented, therefore, few SR initiatives have been successfully employed. 
Table 4. Mean score rankings and Mann-Whitney U test results of Social Responsibility (SR)actors in China and Ghana.

\begin{tabular}{|c|c|c|c|c|c|c|c|c|c|}
\hline \multirow{2}{*}{ Social Responsibility Factors in PPP } & \multicolumn{3}{|c|}{ China } & \multicolumn{3}{|c|}{ Ghana } & \multicolumn{3}{|c|}{ Mann-Whiney U test } \\
\hline & Mean & Rank & Normalization & Mean & Rank & Normalization & U statistics & $\mathbf{Z}$ & Sig \\
\hline Improve resource performance and efficiency & 4.47 & 3 & $0.91 * *$ & 3.42 & 27 & 0.32 & 266.50 & -5.549 & $0.00 *$ \\
\hline Profitability & 4.34 & 4 & $0.85^{* *}$ & 2.98 & 29 & 0.03 & 255.50 & -5.482 & $0.00 *$ \\
\hline Innovation & 3.63 & 9 & $0.52 * *$ & 3.79 & 16 & $0.56^{* *}$ & 762.50 & -0.687 & 0.49 \\
\hline Improve project quality & 4.63 & 2 & $0.98^{* *}$ & 4.44 & 2 & $0.99 * *$ & 743.50 & -0.944 & 0.35 \\
\hline Cost reduction & 3.81 & 8 & $0.61 * *$ & 3.69 & 20 & 0.49 & 770.00 & -0.598 & 0.55 \\
\hline Efficient maintenance & 4.66 & 1 & $1.00 * *$ & 4.21 & 5 & $0.84 * *$ & 530.00 & -3.086 & $0.00 *$ \\
\hline Proper contract & 4.31 & 5 & $0.84 * *$ & 4.23 & 4 & $0.85^{* *}$ & 775.00 & -0.576 & 0.57 \\
\hline Ensure project is completed on time and budget & 3.59 & 11 & 0.51 ** & 3.81 & 15 & $0.57^{* *}$ & 728.00 & -1.014 & 0.31 \\
\hline Support local business & 3.13 & 23 & 0.29 & 3.83 & 14 & $0.58 * *$ & 571.00 & -2.494 & $0.01 *$ \\
\hline Improve local policy & 3.44 & 15 & 0.43 & 3.88 & 10 & $0.62 * *$ & 690.00 & -1.367 & 0.17 \\
\hline Ensure accountability, legitimacy, and transparency & 3.84 & 7 & $0.62 * *$ & 4.46 & 1 & $1.00 * *$ & 511.00 & -3.204 & $0.00 *$ \\
\hline Keep close partnership between stakeholders & 3.56 & 12 & 0.49 & 3.98 & 9 & $0.68^{* *}$ & 772.00 & -0.595 & 0.55 \\
\hline Improve service standard & 3.59 & 10 & $0.51^{* *}$ & 3.69 & 19 & 0.49 & 831.00 & -0.010 & 0.99 \\
\hline Provide jobs & 2.75 & 28 & 0.12 & 4.06 & 8 & $0.74 * *$ & 280.50 & -5.322 & $0.00 *$ \\
\hline Ensure worker health and safety & 3.34 & 17 & 0.39 & 3.87 & 11 & $0.61^{* *}$ & 798.00 & -0.336 & 0.74 \\
\hline Protect human rights & 3.25 & 21 & 0.35 & 3.77 & 17 & $0.55 * *$ & 576.00 & -2.498 & $0.01 *$ \\
\hline Working altruistically for the public good & 2.78 & 27 & 0.13 & 3.62 & 23 & 0.44 & 477.00 & -3.477 & $0.00 *$ \\
\hline Protect cultural heritage & 2.50 & 30 & 0.00 & 2.94 & 30 & 0.00 & 625.00 & -2.003 & 0.05 \\
\hline Appropriate resettling, rehabilitation, and compensation & 3.28 & 19 & 0.36 & 3.46 & 26 & 0.34 & 369.00 & -4.540 & $0.00 *$ \\
\hline Establish a waste emission management system & 3.47 & 13 & 0.45 & 3.83 & 13 & $0.58^{* *}$ & 657.00 & -1.709 & 0.09 \\
\hline Water protection & 3.47 & 14 & 0.45 & 4.37 & 3 & $0.94^{* *}$ & 420.00 & -4.040 & $0.00 *$ \\
\hline Improve climate resilience and air quality & 3.25 & 20 & 0.35 & 3.58 & 25 & 0.42 & 425.00 & -3.929 & $0.00 *$ \\
\hline Improve environmental policy & 3.31 & 18 & 0.38 & 3.77 & 18 & $0.55^{* *}$ & 658.00 & -1.682 & 0.09 \\
\hline Use sustainable design and materials & 4.09 & 6 & $0.74 * *$ & 4.10 & 6 & $0.76^{* *}$ & 757.00 & -0.738 & 0.46 \\
\hline Reduce carbon emission & 3.41 & 16 & 0.42 & 3.58 & 24 & 0.42 & 750.50 & -0.789 & 0.43 \\
\hline Soil protection & 3.03 & 24 & 0.25 & 3.63 & 22 & 0.46 & 733.00 & -0.970 & 0.33 \\
\hline Noise prevention & 3.16 & 22 & 0.30 & 3.23 & 28 & 0.19 & 811.00 & -0.206 & 0.84 \\
\hline Biodiversity protection & 2.84 & 26 & 0.16 & 3.63 & 21 & 0.46 & 743.50 & -0.873 & 0.38 \\
\hline Landfill protection & 3.00 & 25 & 0.23 & 3.83 & 12 & $0.58^{* *}$ & 648.50 & -1.880 & 0.06 \\
\hline Forest protection & 2.69 & 29 & 0.09 & 4.08 & 7 & $0.75^{* *}$ & 231.00 & -5.782 & $0.00 *$ \\
\hline
\end{tabular}


The results of the significance test using Mann-Whitney $U$ are shown in the last column of Table 4. As previously mentioned, the test was conducted at a significance level of 0.05 , thus a significant test value of a SR factor below 0.05 indicates that respondents from China and Ghana have different perceptions on the importance of that SR factor. As presented in the table, 12 SR factors had different views on their importance among the Chinese and Ghanaian respondents. Essentially, the SR factors with significant differences that are ranked higher in China and lower in Ghana relate to the economic efficiency of PPP projects and climate change adaptation. These include: "Improve resource performance and efficiency", "profitability", "efficient maintenance", "appropriate resettling, rehabilitation and compensation", and "improve climate resilience and air quality".

"Improve resource performance and efficiency" is ranked 3rd and 27th by the Chinese and Ghanaian respondents, respectively. In fact, it has a mean difference of 1.05 (4.47 (China)) and 3.42 (Ghana). PPP projects usually utilize a wide range of resources, including land, human, technology, construction and operational materials, and finance. Essentially, these resources have to be efficiently utilized in order to minimize project costs and enhance the value for money [24]. Considering the rapid implementation of PPPs in China, many resources, particularly land, are utilized for PPP projects. Therefore, over the last couple of years, it has become the agenda of many Chinese local governments to ensure the application of smart technologies in PPPs to enhance the efficient utilization of limited resources in China. A typical example is the use of building information modelling in estimating the costs in some Chinese PPP projects. This approach enhances cost efficiency and further ensures optimal allocation of resources. Unlike China, Ghana has implemented very few projects and therefore has not utilized much of the nation's resources for PPP deals. Therefore, enhancing resource performance through the use of smart technologies may not be critical, as indicated by the respondents.

"Profitability", "efficient maintenance", and "appropriate resettling, rehabilitation and compensation" are ranked 4th, 1st, and 19th in China, respectively, whereas in Ghana, they are ranked 29th, 5th, and 26th. Importantly, these SR factors have wide mean differences between China and Ghana: 1.36 (profitability), 0.45 (efficient maintenance), and 0.18 (appropriate resettling, rehabilitation, and compensation). Profitability is generally critical in measuring the economic efficiency of PPP transactions [17]; however, it is more crucial to the private sector organization compared to public institutions [40]. Chan et al. [3] pointed out that the adoption of PPPs in China is generally driven by economic related factors, including profit. This suggests that profitability is considered to be a part of the factors that generally determines the efficiency of PPP projects in China.

This is quite understandable because both the Chinese government and investors have put a lot of capital in PPP projects over the years; therefore, they expect excessive returns on their investments. In fact, in 2016, the World Bank [4] reported that China's PPP investments reached US $\$ 11.4$ billion. Indeed, for the Chinese PPP market to be sustainable, the generation of more profits through efficient risk allocation is critical considering the amount of capital invested over the years. Although, Osei-Kyei and Chan [33] have indicated that profitability is a critical success measure in Ghana, it is not an important social responsibility factor in the Ghanaian context and this may be due to the limited amount of capital invested in the Ghanaian PPP market over the years, i.e., US\$2.05 billion in 2016 [4]. Essentially, this amount of investment is not comparable to that of the Chinese PPP market. Efficient maintenance implies a reduction in the operation and maintenance costs of PPP projects. It entails the adoption of innovative techniques to reduce the running and administration costs of PPP projects. Apparently, to ensure profitability, it is essential that the operation and maintenance costs of PPP projects are kept low. Therefore, is not surprising that the Chinese respondents ranked this SR factor higher compared to their Ghanaian counterparts, who considered profitability as a low critical SR factor. The high ranking of "appropriate resettling, rehabilitation, and compensation" in China compared to Ghana is unsurprising because the compensation and resettlement of persons due to PPP project development have become topical in the Chinese PPP market in the last couple of years. Displaced persons, especially rural dwellers, often complain of inadequate compensation claims for their properties (particularly farm lands) $[60,61]$. Although the Chinese government has enacted 
regulations to curb this situation, more proactive actions are needed to ensure compliance with these policies by local government authorities [60].

"Improve climate resilience and air quality" is directly rated to climate change adaptation. It is ranked 20th with a mean value of 3.25; whereas in Ghana, it is ranked 25th with a mean value of 3.58. Climate resilience refers to the adaptation of the socio-ecological system to stresses imposed by climate change [62]. Indeed, climate change is one of the biggest global challenges in this century. As a result, the adaption and provision of measures to withstand the impact of climate change has become critical. Apparently, China is a leading advocate for the necessity of governments to invest in infrastructure and their capacity to adapt to projected climate impacts; thus, it is understandable that this SR factor is ranked higher compared to Ghana. In recent years, the Chinese government has increased its efforts by introducing policies and regulations that could help investors adopt measures to minimize the emission of harmful gases and also develop infrastructure that is resilience to adverse climate conditions [63]. Although, the government of Ghana has also shown an interest in the need to improve climate resilience and air quality by introducing a climate change framework, practical actions are yet to be seen, particularly for PPP infrastructure projects. In fact, the efforts and enthusiasm by the Chinese government to enhance climate resilience is not the same as that of the Ghanaian government. Therefore, the Ghanaian respondents do not consider this SR factor as being important in Ghana as seen in China.

The SR factors with significant differences that are ranked higher in Ghana and lower in China include "support local business", "ensure accountability, legitimacy, and transparency", "provide jobs", "protect human rights", "working altruistically for the public good", "water protection", and "forest protection". Essentially, these SR factors directly relate to job creation and environmental protection. This finding is in line with the outputs of Osei-Kyei et al. [37], where local economic development, particularly job opportunities, was found to be a significant success measure for PPP projects in Ghana. Over the last two decades, unemployment has been a major challenge to successive governments in Ghana. In fact, the average unemployment rate in Ghana is around $5.41 \%$ [64]. This figure is quite significant considering a country with a population of about 28 million. Importantly, the majority of the unemployed are young adults and due to the unavailability of jobs, many of them are engaged in social vices and fraud [65]. In this regard, with the adoption of the PPP policy, the government of Ghana and other stakeholders can expect that through the numerous activities in PPP project developments, more jobs will be created for local residents. Further, after the completion of PPP projects, it is anticipated that opportunities will be available for local residents to engage in commercial enterprises. Job creation can also be enhanced if private investors, particularly international organizations, support local businesses by subcontracting portions of the PPP activities, particularly repair and maintenance work. Also, the ensuring of accountability and transparency will also contribute to job creation. Indeed, if the PPP process is transparent and free from external influences, better negotiations in terms of the employment of locals will be made. Certainly, when more locals are employed in PPPs, more job opportunities will be available.

Water and forest protection are related to the preservation of the natural environment. During the past few years, the government of Ghana has increased efforts to protect water bodies and the forest reserve. This has become necessary because of the increase in illegal small-scale mining activities, which pollute the water bodies and destroy natural reserves. Notably, PPP project development involves activities that can also possibly deplete the country's national reserves, therefore, the government has instructed local contracting authorities to assess the environmental plan of potential PPP investors prior to negotiations or the awarding of a contract. It is hoped that this directive will help to ensure that the natural reserves and water bodies are preserved.

Unlike Ghana, unemployment is not necessarily a key national challenge in China. The average unemployment rate in China is $4.10 \%$, which is considered as acceptable given that the country has a population of around 1.3 billion [65]. Nonetheless, the Chinese government has put in place a lot of measures to help further decrease the rate and these measures are already in effect [66]. It is therefore understandable as to why the SR factors related to job creation are ranked lower in China than Ghana. 
Undoubtedly, environmental protection is also relevant in China, however, it is ranked lower by the Chinese respondents compared to their Ghanaian counterparts. This is possibly because the Chinese respondents may have considered more pressing SR initiatives, such as resource efficiency and profitability. Therefore, they do not perceive environmental protection as very critical or relevant in the Chinese PPP market. This notwithstanding, the Chinese government has in the past three years made considerable progress on the crackdown of pollution and the destruction of water bodies and natural reserves. An example is the banning of fishing in China's second largest river, the Yellow River. In this regard, water and forest protection may not necessarily be relevant now.

\subsection{Similarities on the Rankings of SR Factors in PPPs in China and Ghana}

Among the 30 SR factors, only one factor (i.e., "improve project quality") emerged as being very critical in both the China and Ghana rankings. "Improve project quality" is ranked second by respondents from both countries. It has mean values of 4.63 and 4.44 for China and Ghana, respectively. Undeniably, project quality has a substantial influence on the satisfaction of users [41]. If private operators improve the quality of service delivered to customers, they are able to gain their confidence and loyalty. This is certainly a business principle that applies everywhere, but not to a specific jurisdiction. However, for private operators to enhance the quality of services delivered, they need to adopt quality control measures. In addition, output specifications must be met. On the contrary, if users are unable to receive good quality services from private operators, they become agitated, which then affects the operation of the PPP project and the investment returns. Therefore, it is critical for investors to ensure that quality is enhanced irrespective of the jurisdiction they operate in.

\section{Recommendations for PPP Practice}

Social responsibility (SR) is important for the promotion of sustainable development through PPPs, however, very few research studies have focused on how SR could be enhanced in PPP procurement. Therefore, this study provides useful implications for practice and serves as a foundation for more empirical research.

- First, improvements on project quality are crucial as this influences the overall satisfaction of users and other stakeholders of the PPP project. To improve quality, proper quality control measures should be adopted. Further, timely repairs and maintenance could enhance the quality of PPP projects, particularly during operation.

- Second, the efficient utilization of resources, such as land, capital, and employees, is an important SR initiative and therefore could help promote sustainability. To efficiently utilize resources, smart technologies, such as Building Information Modelling (BIM), should be used to estimate costs at the early stages. Also, modern forms of construction should be adopted to minimize wastage.

- Third, profitability is essential to ensure the sustainability of PPP markets. For project parties to make substantial profits, they need to adopt smart and digitalized technology in the delivery and operation of their projects.

- Fourth, job creation is critical, particularly in countries with high unemployment rates, such as Ghana. To create more job opportunities, construction and operational works should be subcontracted to local businesses. Further, more local content should be employed in PPP project development. An example is the use of local building materials during construction and operation.

- Lastly, environmental protection, particularly water and forest preservation, is important for the promotion of sustainability. A detailed environmental plan should be prepared and reviewed by environmental protection agencies in the host country. In addition, adequate measures should be adopted to avoid the pollution of water bodies and the emission of harmful gases during the construction and operation of the facility. 
It is believed that if project parties (both public and private) consider the above SR measures carefully, PPP projects will offer wider social benefits and value for money. In addition, the impacts of PPP activities on organizations, society, and the environment and economy will be highly positive.

\section{Conclusions}

This paper evaluated SR factors for sustainable development in PPPs through a comparative study between China and Ghana. First, a systematic review of the past literature was conducted to generate a comprehensive list of SR factors in PPPs. Further, an empirical questionnaire survey was conducted with experienced PPP practitioners in both countries. An initial statistical test using the Kendall's coefficient of concordance analysis indicated a significant level of consistency and association among the responses in each independent group (i.e., China and Ghana). This therefore affirmed the reliability and genuineness of the survey responses for further analysis. The mean score analysis coupled with the range normalization method was used to assess the relative importance of each SR factor in each jurisdiction. Results show that the Ghanaian respondents generally ranked the set of SR factors higher than their Chinese counterparts. In addition, 11 and 18 SR factors emerged as being critical in China and Ghana, respectively. This result implies that the Ghanaian respondents considered most of the SR factors as being very relevant within the Ghanaian PPP market. This is unsurprising because Ghana has implemented few PPP projects, therefore, many of the SR initiatives have not yet been realized compared to China. The Mann-Whitney $U$ test was conducted to ascertain any significant differences on the rankings of the SR factors among the two independent groups. The test results indicate that respondents from China and Ghana perceive the importance of 12 SR factors differently. Of the 12 SR factors, five were ranked higher in China and lower in Ghana; they include "improve resource performance and efficiency", "profitability", "efficient maintenance", "appropriate resettling, rehabilitation, and compensation", and "improve climate resilience and air quality". Apparently, these SR factors directly relate to the economic efficiency of PPP projects and climate change adaptation. The other seven SR factors were ranked higher in Ghana and lower in China, and they are directly related to job creation and environmental protection. They are "support local business", "ensure accountability, legitimacy, and transparency", "provide jobs", "protect human rights", "working altruistically for the public good", "water protection", and "forest protection".

Indeed, the outputs of this study offer several practical implications for practice. First, they inform investors interested in PPPs, particularly in Asia and Africa, of the key SR initiatives that need to be taken into consideration in order to offer sufficient social benefits and to maximize the efficiency of resources. Second, they inform local government authorities of the social, economic, and environmental initiatives that need to be incorporated in the terms and conditions of PPP contracts to enhance sustainable development.

For academics, considering that very little research has been vested in the sustainability assessment of PPPs, this study serves as a foundation for more empirical study. In addition, the study opens discussion as well as extends the international debate on how sustainable development can be achieved through PPPs.

The major limitation of the study is the fact that interviews and case studies were not considered in the overall methodology. Importantly, these methods would have strengthened the validity and generalizability of the research findings. However, the authors take solace from the fact that sustainability is still emerging in PPPs, therefore, this study only serves as a "stepping stone" for further research studies that can adopt case studies or interviews.

Author Contributions: Data curation, R.O.-K., Y.Y.; Formal analysis, R.O.-K., Y.Y.; Methodology, R.O.-K.; Supervision, A.P.C.C.; Validation, C.C. and B.T.; Writing-original draft, R.O.-K.; Writing-review \& editing, R.O.-K., A.P.C.C., Y.K. and C.C.

Funding: This research forms part of a research project entitled "A best practice framework for PPP implementation for infrastructure development in Ghana" from which other papers have been produced with different objective/scope but sharing the same background and methodology. The research project described is fully supported by the Hong Kong PhD Fellowship Scheme from the Research Grants Council (RGC) of the Hong Kong Special Administrative Region and The Hong Kong Polytechnic University, Hong Kong. 
Conflicts of Interest: The authors declare no conflict of interest.

\section{References}

1. Kwak, Y.H.; Chih, Y.; Ibbs, C.W. Towards a comprehensive understanding of public private partnerships for infrastructure development. Calif. Manag. Rev. 2009, 51, 51-78. [CrossRef]

2. Cheung, E.; Chan, A.P. Is bot the best financing model to procure infrastructure projects? A case study of the Hong Kong-Zhuhai-Macau bridge. J. Prop. Investig. Financ. 2009, 27, 290-302. [CrossRef]

3. Chan, A.P.; Lam, P.T.; Chan, D.W.; Cheung, E.; Ke, Y. Drivers for adopting public private partnerships-Empirical comparison between china and Hong Kong special administrative region. J. Constr. Eng. Manag. 2009, 135, 1115-1124. [CrossRef]

4. World Bank. 2016 Private Participation in Infrastructure Annual Update; World Bank Publications: Washington, DC, USA, 2017.

5. Patil, N.A.; Laishram, B. Public-private partnerships from sustainability perspective-a critical analysis of the Indian case. Int. J. Constr. Manag. 2016, 16, 161-174. [CrossRef]

6. Lenferink, S.; Tillema, T.; Arts, J. Towards sustainable infrastructure development through integrated contracts: Experiences with inclusiveness in Dutch infrastructure projects. Int. J. Proj. Manag. 2013, 31, 615-627. [CrossRef]

7. Yu, Y.; Osei-Kyei, R.; Chan, A.P.C.; Chen, C.; Martek, I. Review of social responsibility factors for sustainable development in public-private partnerships. Sustain. Dev. 2018, 26, 515-524. [CrossRef]

8. ISO. ISO 26000, Guidance on Social Responsibility; International Organization for Standardization: Geneva, Switzerland, 2006.

9. Patil, N.A.; Tharun, D.; Laishram, B. Infrastructure development through PPPS in India: Criteria for sustainability assessment. J. Environ. Plan. Manag. 2016, 59, 708-729. [CrossRef]

10. Tam, C. Build-operate-transfer model for infrastructure developments in Asia: Reasons for successes and failures. Int. J. Proj. Manag. 1999, 17, 377-382. [CrossRef]

11. Osei-Kyei, R.; Chan, A.P. Implementation constraints in public-private partnership: Empirical comparison between developing and developed economies/countries. J. Facil. Manag. 2017, 15, 90-106. [CrossRef]

12. Ke, Y.; Wang, S.; Chan, A.P.; Cheung, E. Research trend of public-private partnership in construction journals. J. Constr. Eng. Manag. 2009, 135, 1076-1086. [CrossRef]

13. Roehrich, J.K.; Lewis, M.A.; George, G. Are public-private partnerships a healthy option? A systematic literature review. Soc. Sci. Med. 2014, 113, 110-119. [CrossRef] [PubMed]

14. Xu, Y.; Yeung, J.F.; Chan, A.P.; Chan, D.W.; Wang, S.Q.; Ke, Y. Developing a risk assessment model for PPP projects in China-A fuzzy synthetic evaluation approach. Autom. Constr. 2010, 19, 929-943. [CrossRef]

15. Ameyaw, E.E.; Chan, A.P. Evaluation and ranking of risk factors in public-private partnership water supply projects in developing countries using fuzzy synthetic evaluation approach. Expert Syst. Appl. 2015, 42, 5102-5116. [CrossRef]

16. Thomas, A.; Kalidindi, S.N.; Ananthanarayanan, K. Risk perception analysis of bot road project participants in India. Constr. Manag. Econ. 2003, 21, 393-407. [CrossRef]

17. Wibowo, A.; Mohamed, S. Risk criticality and allocation in Privatised water supply projects in Indonesia. Int. J. Proj. Manag. 2010, 28, 504-513. [CrossRef]

18. Osei-Kyei, R.; Chan, A.P. Comparative analysis of the success criteria for public-private partnership projects in Ghana and Hong Kong. Proj. Manag. J. 2017, 48, 80-92. [CrossRef]

19. Babatunde, S.O.; Perera, S.; Zhou, L.; Udeaja, C. Barriers to public private partnership projects in developing countries: A case of Nigeria. Eng. Constr. Archit. Manag. 2015, 22, 669-691. [CrossRef]

20. Dulaimi, M.F.; Alhashemi, M.; Ling, F.Y.Y.; Kumaraswamy, M. The execution of public-private partnership projects in the UAE. Constr. Manag. Econ. 2010, 28, 393-402. [CrossRef]

21. Qiao, L.; Wang, S.Q.; Tiong, R.L.; Chan, T.-S. Framework for critical success factors of bot projects in china. J. Proj. Financ. 2001, 7, 53-61. [CrossRef]

22. Meng, X.; Zhao, Q.; Shen, Q. Critical success factors for transfer-operate-transfer urban water supply projects in china. J. Manag. Eng. 2011, 27, 243-251. [CrossRef] 
23. Liu, T.; Wilkinson, S. Can the pilot public-private partnerships project be applied in future urban rail development? A case study of Beijing metro line 4 project. Built Environ. Proj. Asset Manag. 2013, 3, 250-263. [CrossRef]

24. Cheung, E.; Chan, A.P.; Kajewski, S. Enhancing value for money in public private partnership projects: Findings from a survey conducted in Hong Kong and Australia compared to findings from previous research in the UK. J. Financ. Manag. Prop. Constr. 2009, 14, 7-20. [CrossRef]

25. Chan, A.P.; Lam, P.T.; Chan, D.W.; Cheung, E.; Ke, Y. Potential obstacles to successful implementation of public-private partnerships in Beijing and the Hong Kong special administrative region. J. Manag. Eng. 2009, 26, 30-40. [CrossRef]

26. Osei-Kyei, R.; Chan, A.P. Developing transport infrastructure in Sub-Saharan Africa through public-private partnerships: Policy practice and implications. Transp. Rev. 2016, 36, 170-186. [CrossRef]

27. Askar, M.M.; Gab-Allah, A.A. Problems facing parties involved in build, operate, and transport projects in Egypt. J. Manag. Eng. 2002, 18, 173-178. [CrossRef]

28. Roehrich, J.K.; Barlow, J.; Wright, S. Delivering European healthcare infrastructure through public-private partnerships: The theory and practice of contracting and bundling. In Managing Public-Private Strategic Alliances, 1st ed.; Research in Strategic Alliances; Das, T.K., Ed.; Information Age Publishing: Charlotte, NC, USA, 2014.

29. Brammer, S.; Walker, H.L. Sustainable procurement in the public sector: An international comparative study. Int. J. Oper. Prod. Manag. 2011, 31, 452-476. [CrossRef]

30. Marques, R.C. Why not regulate PPPs? Util. Policy 2017, 48, 141-146. [CrossRef]

31. Marsilio, M.; Cappellaro, G.; Cuccurullo, C. The intellectual structure of research into PPPS: A bibliometric analysis. Public Manag. Rev. 2011, 16, 763-782. [CrossRef]

32. Ke, Y. Is public-private partnership a panacea for infrastructure development? The case of Beijing National Stadium. Int. J. Constr. Manag. 2014, 14, 90-100. [CrossRef]

33. Osei-Kyei, R.; Chan, A.P. Empirical comparison of critical success factors for public-private partnerships in developing and developed countries: A case of Ghana and Hong Kong. Eng. Constr. Archit. Manag. 2017, 24, 1222-1245. [CrossRef]

34. Reshma, P. A Theoretical Glimpse on Corporate Social Responsibility. Inter. J. Econ. Commer. Bus. Manag. 2017, 4, 44-48.

35. USDAID. Corporate Social Responsibility and Public Private Partnership. Report No. 6; United States Agency International Development: Washington, DC, USA, 2010.

36. Osei-Kyei, R.; Chan, A.P. Risk assessment in public-private partnership infrastructure projects: Empirical comparison between Ghana and Hong Kong. Constr. Innov. 2017, 17, 204-223. [CrossRef]

37. Osei-Kyei, R.; Chan, A.P.; Javed, A.A.; Ameyaw, E.E. Critical success criteria for public-private partnership projects: International experts' opinion. Int. J. Strateg. Prop. Manag. 2017, 21, 87-100. [CrossRef]

38. DANIDA. Corporate Social Responsibility. Ministry of Foreign Affairs; Danish International Development Agency: Phnom Penh, Cambodia, 2018.

39. Pardo-Bosch, F.; Aguado, A. Sustainability as the key to prioritize investments in public infrastructures. Environ. Impact Assess. Rev. 2016, 60, 40-51. [CrossRef]

40. Couth, R.; Trois, C. Sustainable waste management in Africa through CDM projects. Waste Manag. 2012, 32, 2115-2125. [CrossRef] [PubMed]

41. Horsley, A.; France, C.; Quatermass, B. Delivering energy efficient buildings: A design procedure to demonstrate environmental and economic benefits. Constr. Manag. Econ. 2003, 21, 345-356. [CrossRef]

42. Wang, N.; Wei, K.; Sun, H. Whole life project management approach to sustainability. J. Manag. Eng. 2013, 30, 246-255. [CrossRef]

43. Massoud, M.; El-Fadel, M.; Malak, A.A. Assessment of public vs private MSW management: A case study. J. Environ. Manag. 2003, 69, 15-24. [CrossRef]

44. Osei-Kyei, R.; Chan, A.P.; Yu, Y.; Chen, C.; Dansoh, A. Root causes of conflict and conflict resolution mechanisms in public-private partnerships: Comparative study between Ghana and China. Cities 2018. [CrossRef]

45. Koppenjan, J.F. Public-Private Partnerships for green infrastructures. Tensions and challenges. Curr. Opin. Environ. Sustain. 2015, 12, 30-34. [CrossRef] 
46. Bennett, A. Sustainable public/private partnerships for public service delivery. Nat. Resour. Forum 1998, 22, 193-199. [CrossRef]

47. Regan, M.; Smith, J.; Love, P. Infrastructure Procurement: Learning from Private-Public Partnership Experiences 'Down Under'. Environ. Plan. C Gov. Policy 2011, 29, 363-378. [CrossRef]

48. Kyvelou, S.; Marava, N.; Kokkoni, G. Perspectives of local public-private partnerships towards urban sustainability in Greece. Int. J. Sustain. Dev. 2011, 14, 95. [CrossRef]

49. Lund-Thomsen, P. Assessing the Impact of Public-Private Partnerships in the Global South: The Case of the Kasur Tanneries Pollution Control Project. J. Bus. Ethics 2009, 90, 57-78. [CrossRef]

50. Wuisan, L.; Van Leeuwen, J.; Van Koppen, C. (Kris) Greening international shipping through private governance: A case study of the Clean Shipping Project. Mar. Policy 2012, 36, 165-173. [CrossRef]

51. Zegras, P.C.; Grillo, C. Private Road to Sustainable Mobility? Transp. Res. Rec. 2014, 2450, 17-25. [CrossRef]

52. Haughton, G.; McManus, P. Neoliberal Experiments with Urban Infrastructure: The Cross City Tunnel, Sydney. Int. J. Urban Reg. 2011, 36, 90-105. [CrossRef]

53. Brereton, M.; Temple, M. The New Public Service Ethos: An Ethical Environment For Governance. Public Adm. 1999, 77, 455-474. [CrossRef]

54. Abramov, I. Building Peace in Fragile States - Building Trust is Essential for Effective Public-Private Partnerships. J. Bus. Ethics 2009, 89, 481-494. [CrossRef]

55. Bossink, B.A. A Dutch public-private strategy for innovation in sustainable construction. Constr. Manag. Econ. 2002, 20, 633-642. [CrossRef]

56. Martins, A.C.; Marques, R.C.; Cruz, C.O. Public-private partnerships for wind power generation: The Portuguese case. Energy Policy 2011, 39, 94-104. [CrossRef]

57. Clark, W.W. Partnerships in creating agile sustainable development communities. J. Clean. Prod. 2007, 15, 294-302. [CrossRef]

58. Siegal, S. Nonparametric Statistics for the Behavioral Sciences; McGraw-Hill: New York, NY, USA, 1956.

59. Lam, P.T.; Javed, A.A. Comparative study on the use of output specifications for Australian and UK PPP/PFI projects. J. Perform. Constr. Facil. 2013, 29, 04014061. [CrossRef]

60. Zhao, B. Land expropriation, protest, and impunity in rural china. Focaal 2009, 2009, 97-105. [CrossRef]

61. Faure, A. Public international law debate concerning forced evictions in China. In Proceedings of the III Regional Conference on Social and Economic Human Rights, San Diego, CA, USA, 15 March 2015.

62. Tyler, S.; Moench, M. A framework for urban climate resilience. Clim. Dev. 2012, 4, 311-326. [CrossRef]

63. Fang, J.; Yu, G.; Liu, L.; Hu, S.; Chapin, F.S. Climate change, human impacts, and carbon sequestration in china. Proc. Natl. Acad. Sci. USA 2018, 115, 4015-4020. [CrossRef] [PubMed]

64. Trading Economics. Ghana Unemployment Rate 1991-2018. 2018. Available online: https:// tradingeconomics.com/ghana/unemployment-rate (accessed on 4 September 2018).

65. Sintim-Aboagye. The Threats of Youth Unemployment in Ghana. 2018. Available online: https://www. ghanaweb.com/GhanaHomePage/NewsArchive/The-threats-of-youth-unemployment-in-Ghana-622529 (accessed on 4 September 2018).

66. Trading Economics. China Unemployment Rate 2002-2018. 2018. Available online: https:// tradingeconomics.com/china/unemployment-rate (accessed on 4 September 2018).

(C) 2019 by the authors. Licensee MDPI, Basel, Switzerland. This article is an open access article distributed under the terms and conditions of the Creative Commons Attribution (CC BY) license (http://creativecommons.org/licenses/by/4.0/). 